Канд. техн. наук О.М. Костенніков, К.К. Сфимова

\title{
АНАЛІЗ ОРГАНІЗАЦІї МІСЦЕВОЇ РОБОТИ ДІЛЬНИЦЬ
}

Представив д-р техн. наук, професор О.М. Огар

Постановка проблеми у загальному вигляді, іiї зв'язок із важливими науковими та практичними завданнями. Протягом всієї історії розвитку залізничного транспорту спеціалісти удосконалюють теорію i практику експлуатаційної роботи, приділяючи значну увагу організації місцевої роботи на станціях і дільницях. 
Місцева робота включає в себе розвезення місцевого вантажу до пунктів призначення; передачу місцевого вантажу на інші підрозділи даної залізниці; забезпечення станцій навантаження порожніми вагонами; вивантаження i навантаження вагонів; забезпечення своєчасного відправлення місцевих вагонів після закінчення вантажних операцій [2].

Напрямком розвитку теорії місцевої роботи $\epsilon$ вирішення цілого ряду оптимізаційних завдань:

- змінно-добового

планування

місцевої і вантажної роботи залізниць та дирекцій;

- поточного планування поїзної роботи на технічних станціях;

- поточного планування розвезення й забирання місцевого вантажу на дільницях;

- складання планів-графіків місцевої роботи;

- оптимізації плану формування місцевих поїздів;

- оптимального прокладання місцевих поїздів на графіку руху;

- оптимізації роботи на проміжних станціях;

- оптимального розподілу порожніх вагонів під навантаження;

- оптимізації подач i черговості обслуговування вантажних фронтів.

Проблема поточного планування поїзної і місцевої роботи дільниць є однією із найбільш цікавих завдань в експлуатації залізничного транспорту i разом 3 тим недостатньо вирішеною, тому на сьогоднішній день виникає потреба в проведенні аналізу організації місцевої роботи 3 урахуванням вищенаведених факторів і в умовах використання новітніх автоматизованих технологій.

Мета. Провести аналіз існуючої технології організації місцевої роботи на залізницях України.

Виклад основного матеріалу. Керування поїзною та маневровою роботою на дільницях здійснюється поїзними диспетчерами дорожнього центру управління 3 перевезення вантажів i пасажирів. Метою планування місцевої роботи дирекції $\epsilon$ забезпечення (в конкретних умовах кожної доби або зміни) виконання плану навантаження i вивантаження.

Оперативне планування поїзної та вантажної роботи передбачає розроблення добових i змінних планів роботи Укрзалізниці, залізниці, дирекцій і станцій. Добовий план розробляється i затверджується до 13-00 години доби, що передує плановій добі, 3 відокремленням завдань на першу половину доби, i повідомляється на лінійні станції підрозділів не пізніше 15-ї години. Основною формою планування $\epsilon$ план роботи дирекції - дільниць станцій на зміну. Він складається на основі добового і змінного завдання управління залізниці. Розміри планування навантаження i вивантаження залежать від положення станцій до початку періоду, що планується, наявності місцевого вантажу на дирекції до розвозу і на місцях, інформації про підхід вантажу і технологічних норм на обробку поїздів i вагонів розрахованих 3 урахуванням маневрових засобів і рівня механізації вантажних робіт на станціях, кількості порожніх вагонів для забезпечення заявок на навантаження [1].

При складанні плану місцевої роботи враховується добова i внутрішньодобова нерівномірність прибуття вагонів під вивантаження i підведення порожніх від навантаження, а також варіанти розвезення вагонів під вивантаження і забирання після навантаження резервними, вивізними $\mathrm{i}$ диспетчерськими локомотивами, за рахунок чого прискорюється доставка вагонів. Обслуговування станцій дільниці тим чи іншим локомотивом здійснюється за вказівкою поїзного диспетчера виходячи 3 оперативної ситуації на дільниці.

Добове планування можливо умовно розподілити на планування вивантаження i навантаження вагонів по дільницях. Добове 
планування навантаження виконується на підставі таких даних:

- виконання плану навантаження за попередню добу, наявність невивантажених вагонів і вагонів, що перебувають під вивантаженням на станціях дирекції;

- підхід вагонів під навантаження до станцій дирекції та дільниці в складі місцевих поїздів (розвезення) і транзитних поїздів (групи відчеплення), а також поїздів у розформування на технічних станціях дирекції;

- інформація про можливі обмеження по вивантаженню вагонів (тимчасове закриття вантажних фронтів тощо).

В загальному вигляді план вивантаження вагонів визначається за формулою [4]

$$
B=N_{n i \partial x}+N_{\partial и р}+N_{\text {нев }}-N_{в}
$$

де $N_{n i d x}$ - кількість вагонів на підході до станцій дирекції в складі місцевих і транзитних поїздів, ваг;

$N_{\text {дир }}$ - наявність місцевих вагонів на станціях дирекції під вивантаження на інші станції дирекції, ваг;

$N_{\text {нев }}$ - наявність невивантажених вагонів на станціях дирекції, ваг.;

$N_{\text {в }}$ - наявність вагонів на станціях дирекції під вивантаженням,ваг.

Добове планування навантаження виконується на підставі заявок вантажовідправників на навантаження у вагони, в тому числі відправницькими маршрутами. Співробітники ДЦУ спільно 3 відділом комерційної роботи та маркетингу повинні зробити аналіз виконання плану навантаження за минулу добу на звітній період. При цьому необхідно оцінювати:

- загальне виконання станціями дирекції плану навантаження за родом рухомого складу, родом вантажу (у вагонах і тоннах), за вантажовідправниками;
- недовантаження, що допущені за попередню добу i які потребують виконання в наступній добі, причини недовантаження;

- наявність вагонів під навантаженням на звітній період.

Працівники відділу станцій розглядають можливість забезпечення заявок на навантаження порожніми вагонами, які перебувають на дирекції, звільняються 3-під вивантаження або надходять під вивантаження, формують та видають завдання для станцій (маневровим диспетчерам сортувальних станцій, черговим по станціях, на яких є ПТО) на відбирання i підготовку вагонів під навантаження, а також проект запиту в ДЦУ для надсилання додаткових порожніх вагонів необхідного роду та придатності.

Таким чином, проект плану навантаження формується таким чином:

$$
H=3+N_{\text {нед }}+N_{H},
$$

де 3 - заявки, які прийняті залізницею на перевезення вантажів у вагонах, ваг;

$N_{\text {нед }}$ - допущені 3 вини залізниці або вантажовідправника недовантаження за минулу добу, ваг;

$N_{н}$ - кількість вагонів, які перебувають під навантаженням на звітний період, ваг.

Для більш точного планування розмірів навантаження, вивантаження й організації виконання цих планів ДНН або заступник ДНН щодобово о 10-й і 15-й годині проводить селекторну нараду 3 начальниками станцій, на якій робить оперативний розбір виконання плану минулої доби й уточнює наявність порожніх вагонів, а також можливості використання вагонів із-під вивантаження, дає завдання кожній станції на наступну добу. Після уточнення через ДНЦО вищезазначеної інформації про вивантаження та навантаження, начальник відділу станцій або його заступник дає завдання черговому по дирекції про 
розвезення та забирання місцевого вантажу по станціях дільниці, а черговий по дирекції передає наказ черговому по регіону дорожнього центру управління 3 перевезення вантажів і пасажирів.

Розвезення місцевого вантажу по станціях дільниці та забирання вагонів із станцій здійснюється збірними поїздами, а також диспетчерськими локомотивами [3]. Планування роботи збірного поїзда на дільниці здійснює поїзний диспетчер по узгодженню з начальником відділу станцій дирекції (заступником начальника відділу станцій) або черговим відповідальним працівником дирекції. Відчеплення вагонів від збірного поїзда виконується на станціях, де закріплений маневровий локомотив 3 подальшим довезенням місцевого вантажу на станції диспетчерським локомотивом. Маневрова робота на станціях дільниць виконується маневровими локомотивами ЧМЕ 3.

На сьогодні забезпечення процесу поточного планування засобами АСУ недостатньо в плані підтримки прийняття управлінських рішень. Планування подач i забирань вагонів безпосередньо до вантажних фронтів виконується начальником станції, а для невеликих проміжних станцій $з$ невеликими обсягами роботи - начальником опорної станції.

При існуючій системі організації оперативного планування й управління місцевою роботою, коли поїзний диспетчер зосереджує основну увагу на організації поїзної роботи дільниці (пропуску вантажних поїздів), а розвезення місцевих вагонів організується, як кажуть, «по можливості», за винятком випадків, коли збірні, вивізні і передаточні поїзди відправляються і прямують за твердими нитками графіка руху поїздів. Функції планування накопичення составів вивізних та передаточних поїздів на сортувальних i великих дільничних станціях покладені повністю на маневрових диспетчерів станцій, завдання яких - забезпечити «виштовхування» поїздів 3 власної станції за умови виконання середньої ваги сформованого поїзда. Маневровий диспетчер, як правило, не може відслідкувати постійно ситуацію на станціях прилеглого району місцевої роботи, в тому числі на сусідніх станціях вузла, i не може прийняти рішення, яке покращить взаємодію станцій і прискорить проходження місцевих вагонопотоків, що нерідко призводить до втрати часу при накопиченні і формуванні місцевих поїздів, виникнення фактів невиконання термінів доставки вантажів, несвоєчасного підведення порожніх вагонів під навантаження і завантажених під вивантаження.

\section{Висновок та перспективи} подальших досліджень. Аналіз загального часу доставки вантажу від станції відправлення до станції призначення вказує на те, що в існуючій технології доставки найбільше часу займає: очікування забирання зі станції навантаження та простій вагонів на станціях переробки. Отже, виникає необхідність удосконалення організації місцевої роботи для зменшення вищезазначених простоїв вагонів за рахунок більш повного використання математичного апарату для моделювання технології роботи на ЕОМ і вирішення завдань в оперативних умовах.

\section{Список літератури}

1. Інструкція 3 оперативного планування поїзної і вантажної роботи на залізницях України [Текст]: № 969-Ц3, ЦД-0052: затв. наказом Укрзалізниці 15.12.04. - К.: Укрзалізниця, 2004. 
2. Костєнніков, О.М. Регулювальні заходи для оперативного управління місцевою роботою при збільшенні обсягів перевезень сезонних вантажів [Текст] / О.М. Костєнніков, В.М. Запара, Д.І. Мкртичьян, О.В. Ковальова // Зб. наук. праць. - Харків: УкрДАЗТ, 2009. Вип. 111. - С. 48-57.

3. Нурмухамедов, Р.3. Рациональная организация местной работы железных дорог [Текст] / Р.3. Нурмухамедов. - Ташкент: Мехнат, 1990. - 203 с.

4. Прилепин, Е.В. Методы оперативного управления доставкой местного груза на отделении железной дороги [Текст]: автореф. дис. ... канд. техн. наук: 05.22.08 / Е.В. Прилепин, [ВНИИАС МПС России]. - М., 2004. - 22 с.

Ключові слова: місцева робота, поїзний диспетчер, оптимальний план роботи дільниці, вагонопотік.

\section{Анотаціï}

Проаналізовано стан місцевої роботи на дільницях залізниць України. Зроблено висновок про необхідність більш широкого використання сучасних інформаційних технологій при вирішенні завдань поточного планування місцевої роботи.

Проанализировано состояние местной работы на участках железных дорог Украины. Сделан вывод о необходимости более широкого использования современных информационных технологий для решении задач текущего планирования местной работы.

The state of the local work on railroads Ukraine. The conclusion about the need for more extensive use of modern information technologies for solving problems of the current planning of local work. 